\title{
In Memoriam: Professor Orhan Cura
}

\author{
Obituary \\ Tayfun Kirazlı 10 \\ Department of Otorhinolaryngology, Ege University School of Medicine, İzmir, Turkey
}

ORCID iD of the author: T.K. 0000-0002-5284-8842.

Cite this article as: Kirazlı T. In Memoriam: Professor Orhan Cura. Turk Arch Otorhinolaryngol 2020; 58(2): 75-7.

\section{Corresponding Author:} Tayfun Kirazlı, tayfunkirazli@gmail.com

Content of this journal is licensed under a Creative Commons Attribution 4.0 International License. Available online at www.turkarchotolaryngol.net
On May 14, 2020 we bid farewell to Professor Orhan Cura, founder of Ege University's Department of Otolaryngology, a great scientist, a dauntless advocate of Atatürk's principles and reforms, a nature lover and great fisher, but above all a person who cared about family ties and family values, a father not only to his kin but also to us. In the words of Professor Övünç Günhan, his closest colleague, he is now in the "ultimate realm."

When I was asked to write a tribute to Professor Cura to be published in a scientific journal the first thought that came to my mind was how to fit such a productive life into a short text. My Professor's voice, uttering his most common expressions, resounded in my ears: "Can you hide a spear in a bag, my son?' It was best to leave the task to himself. It was impossible for me to separate his scientific personality from the other aspects of his life, nevertheless his world view. Those who know him well know that he lived life in all its reality. With this approach he had penned his memoirs and shared with me, as well as his family. "I want to give to the young of the family, to the extent possible, a chronological account of the memories that left a mark on me. Professor Orhan Cura, MD (March 24, 2014). So, using his memoirs that he began with this introduction, I aimed to celebrate his life in his own words.

Professor Cura was born in İzmir. His father Hüseyin Hulki Cura was also an Ear Nose and Throat (ENT) specialist. In official documents his birth date is recorded as October 1, 1929, but in his memoirs he wrote: "About ten years ago I saw my father's note on the last page of a Koran that I found

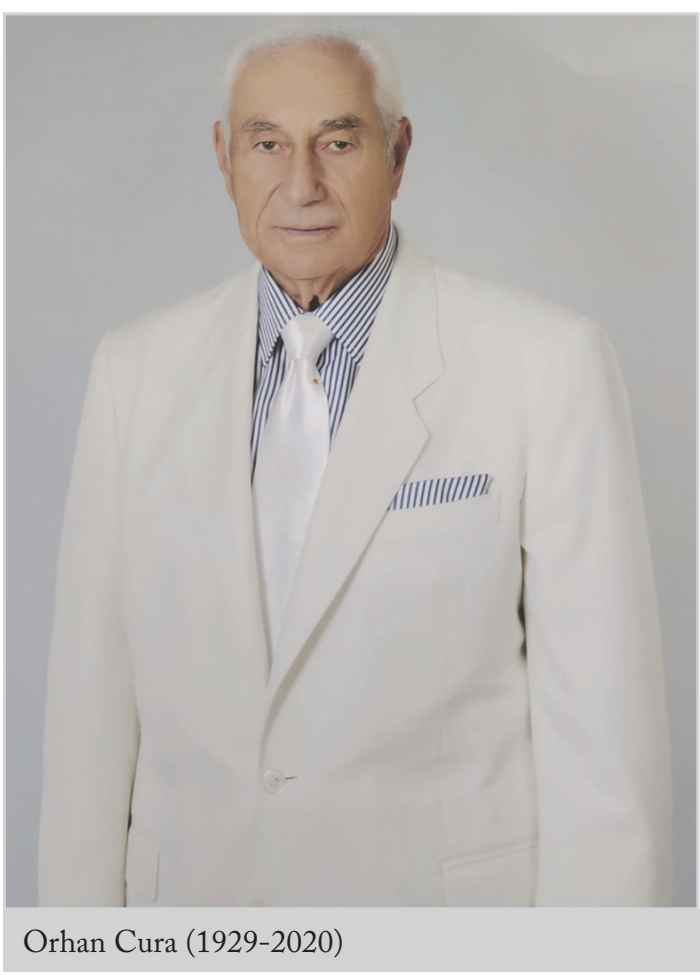

at home. His note, written in the Ottoman alphabet, read, 'My son Orhan was born on Friday evening, November 17, 1928'."

He wrote that he had decided on choosing his father's profession at a very young age. "You should go to the lycée Saint Joseph. All medical prescriptions are written in French, and when you don't know the language, you will find it difficult to even prescribe 'eau oxygènée." Upon his grandfather's words he studied at the French Lycée Saint Joseph first in İzmir (1940-1944), then in İstanbul (1944-1947). 


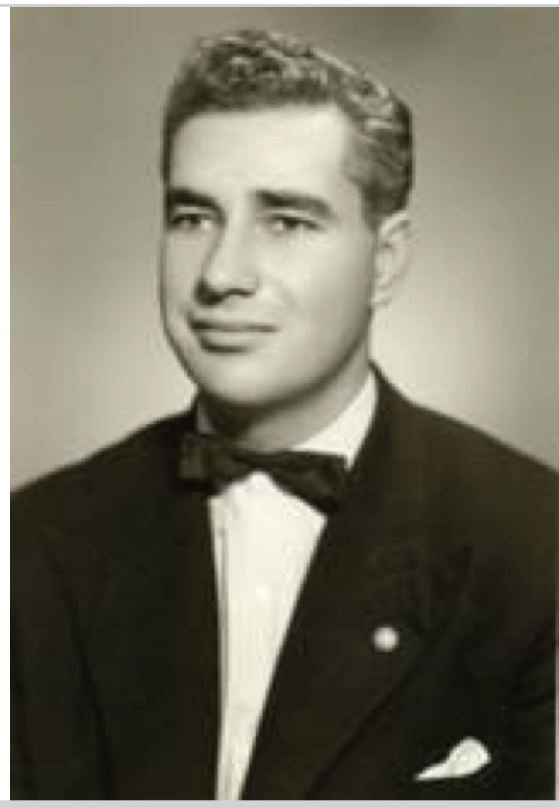

Figure 1. Orhan Cura as a resident

After completing his foundation year (1947) in Ankara University School of Medicine, he transferred to İstanbul University's School of Medicine from where he graduated in 1953. After completing his military service, he served as a resident in the ENT Department of İzmir State Hospital and became an ENT specialist in 1957.

He always emphasized the importance of being able to use both hands equally in ENT. In his memoirs he wrote that his father had him start on "mandolin lessons at the age of seven to strengthen the left hand." Another advice he received from his father was that ENT interns should not practice on patients; rather, to avoid any inconvenience to patients, should first practice by examining each other and providing their feedback to one another to improve their skills. He made this approach an essential part of the education we gave to interns in our department: "Serventeen years on, I became a professor and began telling the stories of my father's advices on my first lecture to all our intern groups."

On October 1, 1957 he was assigned by Professor Ordinarius Muhittin Erel, MD, the founding Rector of the Ege University, as a member of the founding specialists board of Ege University's School of Medicine at the İzmir State Hospital ENT Department. He became associate professor in 1962. In 1966 he went to France on NATO scholarship for one year and worked in Professor Michel Portmann's ENT Clinic and took further training courses at University Bordeaux II. In 1967 he received his professorship and became the Chairman of the ENT Department of Ege University School of Medicine, where he served for 29 years until his retirement on October 1, 1996.

After one of the most important milestones of his life, his associate professorship examination, followed by a celebration luncheon, he and the jury members realized the first of what would later become and still is a tradition among the professors of our department. Describing this in his memoirs he wrote, "After lunch, Dr. Övünç Günhan and I took my mother to the hotel and

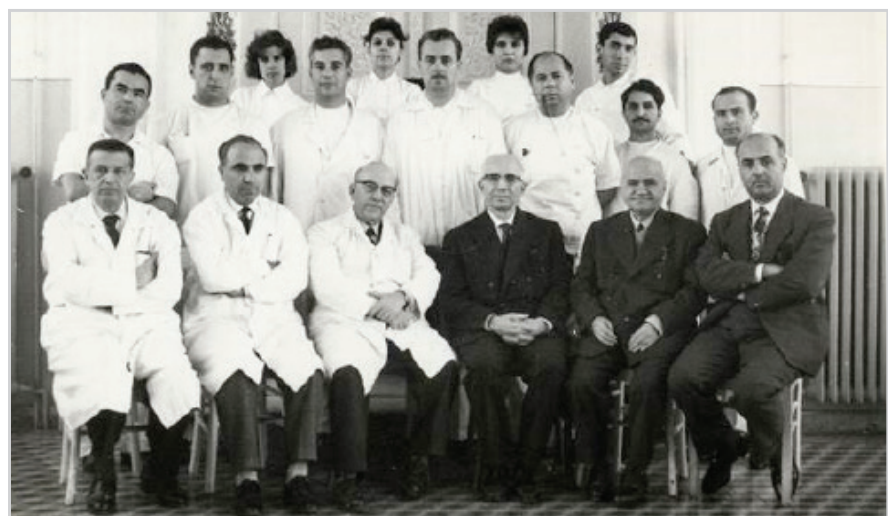

Figure 2. İzmir State Hospital (1960s)

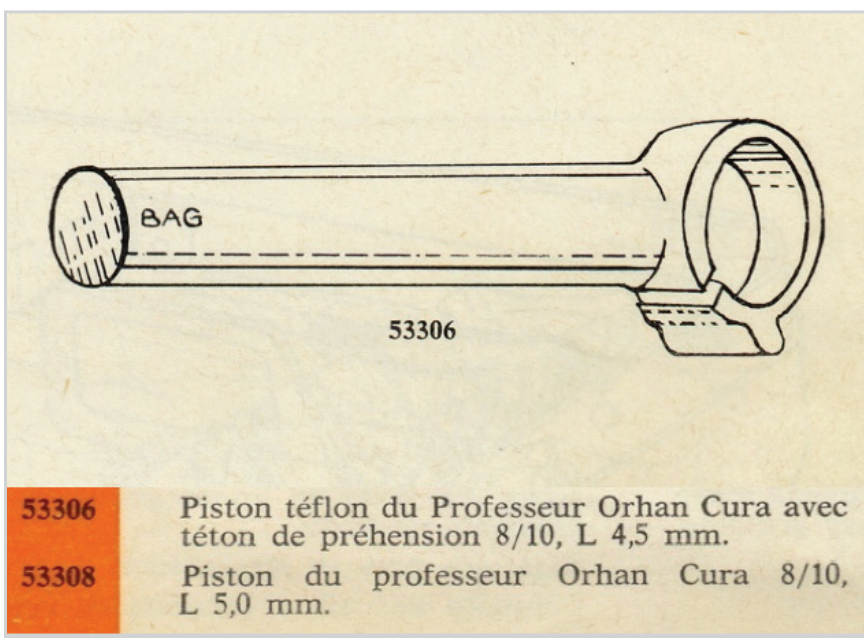

Figure 3. Patented stapes teflon piston on behalf of Orhan Cura

then went to the Atatürk Mausoleum where I pledged in the presence of our leader to serve my country according to his principles until my last breath."

With his interest in all areas, Professor Cura can be described as an intellectual of the ENT field. In a period when the only resource of knowledge was books, he would constantly read as he had a good command of the French language, each morning he would tell us about the novelties and define thesis topics. He had a special interest for and worked in otologic surgery, laryngeal surgery, phoniatrics and audiology as meta-specialties. A creative personality, he designed and patented many surgical instruments and prostheses for otologic and laryngeal treatment. In his memoirs he wrote that his skill in tools design developed after his father sent him with some tools to the technical school to have them repaired: "My father had sent examples of tools like decollator, retractor, stylet, tongue depressors that were used in tonsillectomy and nasal deformity surgeries and asked to have their copies produced. For a whole week I went to the School and watched them work and oriented the artisans about especially some subtle details such as the weight and the inner balance of the tools. Two impeccable copies of each of the original tools were produced and delivered to me. Following this, within about the two decades of my academic career I designed nine original ENT instruments and two micro-prosthetic models." 
In his retirement ceremony on October 1, 1996, he was honored with an Outstanding Service Award by the Senate of Ege University. In the ceremony Professor Cura presented a summary of his work: "In the beginning, our studies mostly focused on audiology. We first put supraliminal tests to practice. Then we conducted long-term studies to phonetically examine the oral and written Turkish. Therewith, we scientifically prepared a list of phonetically irregular Turkish words to be used in speech audiometry. Laryngeal microsurgery was introduced in 1972; in 1976 the molding technique where the graft is prepared from the patient's own connective tissue were introduced in eardrum operations; and in 1978 electrocochleography became a routine practice. In the 1970s phoniatrics was given great importance in regard of the shortcomings in the field of voice disorders (phoniatrics) in our country. A modern phonology laboratory was established with state-of-the-art electronic tools. In the 1980s, reconstructive laryngectomy operations were performed in some larynx cancers by removing the cancerous part of the larynx and connecting the hy-

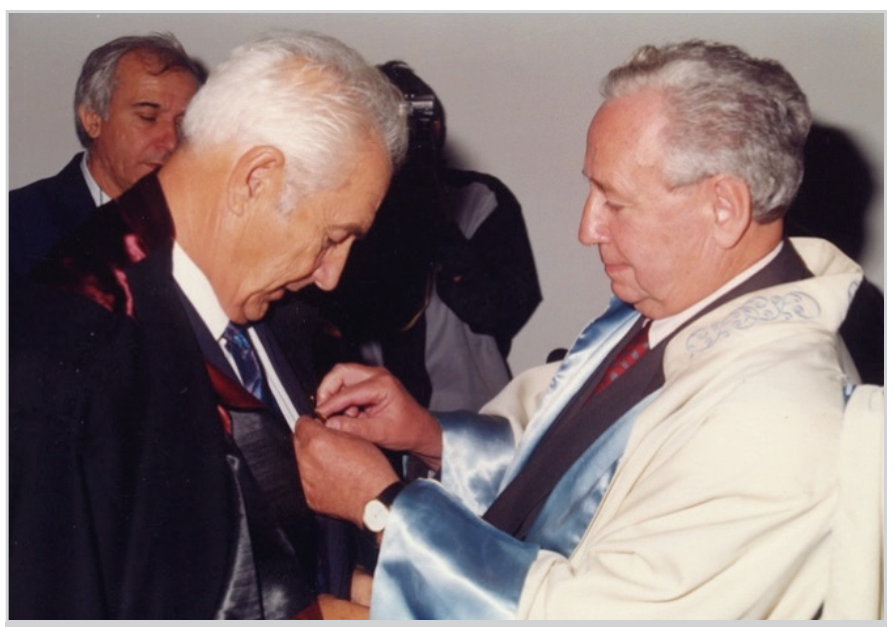

Figure 4. Ege University Distinguished Service insignia (October 1, 1996) oid bone to the trachea to allow the patient to breathe through the mouth. Also, a special original suture set was introduced to be used in patients with bilateral closed vocal cord paralysis to allow them to breathe through the mouth without placing an external cannula under the larynx. In 1979, we made interesting studies on electro-rhinomanometry that demonstrated the importance of nasal breathing during physical effort. In 1992 endoscopic sinus surgery became a routine practice. In 1996, the last year of my career life, the first cocblear implant placement surgery was performed in our department."

After he retired he was invited to a meeting in Bursa. "What are the things that you wished to achieve but could not?" His response to this question that he was asked by one of our associate professor colleagues shows, in fact, his worldview: "I thought for a moment. As, unlike the fashionable elite, I had no extravagant dreams such as owning a private helicopter, a magnificent mansion by the Bosphorus, or a deluxe yacht, I saw that I had achieved everything that I wished for. There is nothing that I wanted to but could not accomplish."

He was a candid person who always sought to do the right thing with an endless working energy, who was capable of criticizing himself to do better-in short, he was a "self-knowing person": "My family raised me very differently. I never disrespect my elders. I am always tolerant and helpful. I never break my word. Being an admirer of the nature, a sailor and hunter, I am physically strong, neither do I fear working hard nor does lack of sleep affect me."

We lost an irreplaceably great professor. His presence was a support to us until his very last days. We will always cherish his memory and preserve his values on the path that he opened through great contributions to our profession and to science. May he rest in peace.

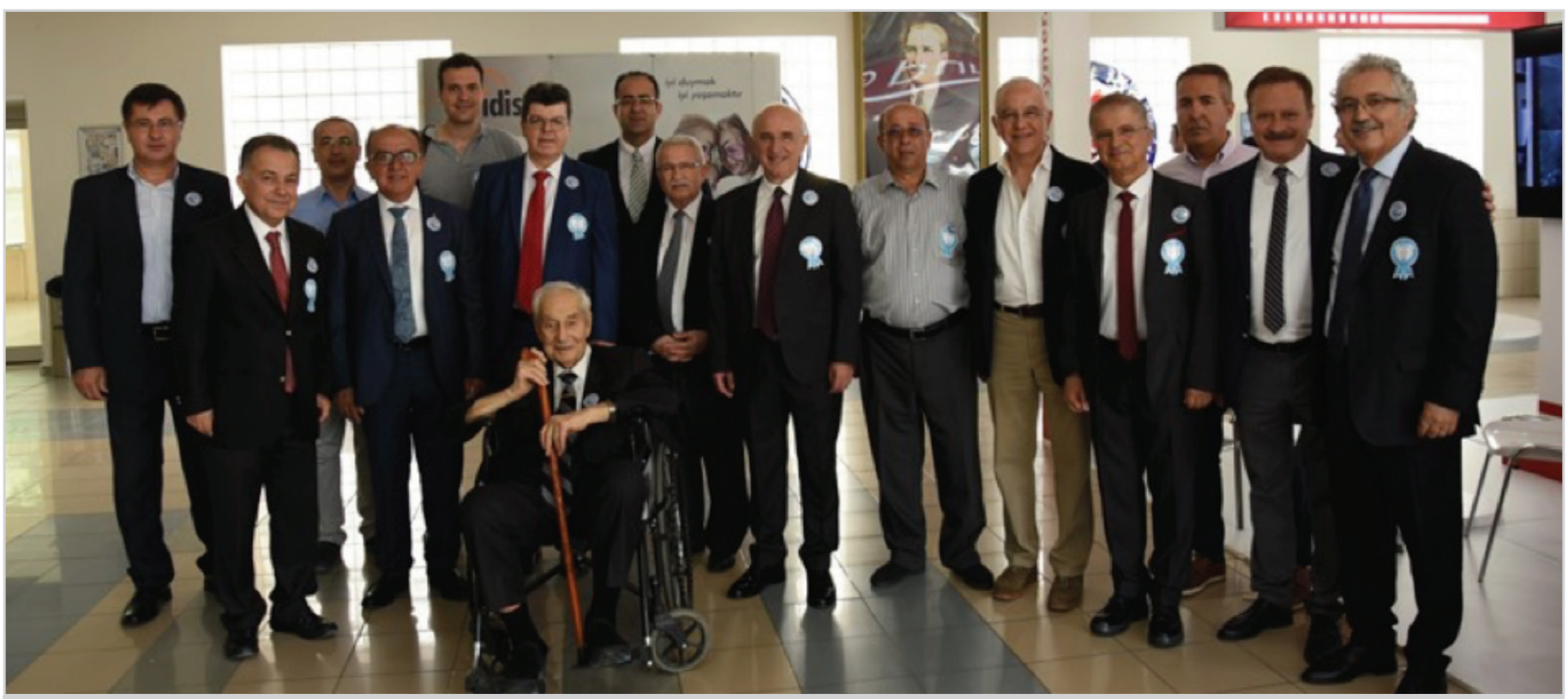

Figure $5.60^{\text {th }}$ Foundation Meeting of ENT Department of Ege University School of Medicine, 2018 